\title{
Morphological and molecular characteristics do not confirm popular classification of the Brazil nut tree in Acre, Brazil
}

\author{
P.S. Sujii ${ }^{1}$, E.T.M.B. Fernandes ${ }^{2}$, V.C.R. Azevedo ${ }^{3}$, A.Y. Ciampi ${ }^{3}$, \\ K. Martins ${ }^{4}$ and L.H. de O. Wadt ${ }^{5}$ \\ ${ }^{1}$ Departamento de Genética, Biologia Molecular e Bioagentes, \\ Universidade Estadual de Campinas, Campinas, SP, Brasil \\ ${ }^{2}$ Secretaria de Extensão Agroflorestal e Produção Familiar, \\ Rio Branco, AC, Brasil \\ ${ }^{3}$ Laboratório de Genética Vegetal, \\ Embrapa Recursos Genéticos e Biotecnologia, Brasília, DF, Brasil \\ ${ }^{4}$ Departamento de Biologia, Universidade Federal de São Carlos, \\ Campus Sorocaba, Sorocaba, SP, Brasil \\ ${ }^{5}$ Empresa Brasileira de Pesquisa Agropecuária, Rio Branco, AC, Brasil \\ Corresponding author: L.H. de O. Wadt \\ E-mail: lucia.wadt@embrapa.br
}

Genet. Mol. Res. 12 (3): 4018-4027 (2013)

Received December 12, 2012

Accepted August 5, 2013

Published September 27, 2013

DOI http://dx.doi.org/10.4238/2013.September.27.3

ABSTRACT. In the State of Acre, the Brazil nut tree, Bertholletia excelsa (Lecythidaceae), is classified by the local population into two types according to morphological characteristics, including color and quality of wood, shape of the trunk and crown, and fruit production. We examined the reliability of this classification by comparing morphological and molecular data of four populations of Brazil nut trees from Vale do Rio Acre in the Brazilian Amazon. For the morphological analysis, we evaluated qualitative and quantitative information of the trees, fruits, and seeds. The molecular analysis was performed using RAPD and ISSR markers, with cluster analysis. Significant differences were found between the two types of Brazil nut trees for the characters diameter at breast height, fruit yield, fruit size, 
and number of seeds per fruit. Despite the significant correlation between the morphological characteristics and the popular classification, we observed all possible combinations of morphological characteristics in both types of Brazil nut trees. In some individuals, the classification did not correspond to any of the characteristics. The results obtained with molecular markers showed that the two locally classified types of Brazil nut trees did not differ genetically, indicating that there is no consistent separation between them.

Key words: Amazon; Bertholletia excelsa; Ethnoclassification; Non-timber forest products

\section{INTRODUCTION}

Bertholletia excelsa Bonpl. (Lecythidaceae), known as Brazil nut tree, is a species that occurs in mainland areas in a large part of the Amazon Basin. It is important both ecologically, since it is a dominant tree that contributes to forest dynamics and succession, and socially, since thousands of families in Brazil, Bolivia, and Peru live off of harvesting Brazil nuts. The nuts are greatly appreciated due to their nutritional value (rich in selenium and protein) and the oil obtained from them, which is used in cosmetics. Although its wood is excellent for use in construction, cutting down Brazil nut trees is prohibited by law (IBDF Normative Instruction No. 001/80, according to the Forest Code - Federal Law No. 4771) because of its social and economic importance. The species is included in the vulnerable category of the IUCN Red List of Threatened Species (International Union for Conservation of Nature and Natural Resources) and is part of the official list of species of endangered flora of the Brazilian Ministry of the Environment (MMA, 2008).

Practically the entire world production of Brazil nuts comes from small extractive communities, which puts it in a privileged position in markets that value social and environmental issues (fair trade certification). The steadily growing demand for Brazil nuts, both by the food and cosmetic industries (Fonseca, 2002), generates the need for basic studies on the biology and population dynamics of the species, as well as the characterization and understanding of the genetic mechanisms responsible for maintaining it (reproduction and recruitment of new individuals).

Brazil nut trees are classified by the local population of the States of Acre, Amazonas, Roraima, Rondonia, and Mato Grosso into types: red and white in Acre, Rondônia and Amazonas; pink and white in Roraima; and pink, rajada (striped), and mirim (small) in Mato Grosso (Camargo, 2010). In the State of Acre the popular classification is based on the color and quality of wood as well as the size of the tree. Red Brazil nut trees have red wood and are believed to have a better quality for construction, with thicker trunk and branches; they also have a larger crown and greater fruit production when compared to the white Brazil nut trees (Fernandes, 2007).

The popular classification of some tree species has been verified using cluster analysis based on genetic and morphological differences. In Amazonas, Clement (2002) found that three races of peach palm (Bactris gasipaes Kunth) ethnoclassified by morphological characteristics consisted of only two genetically distinct races. Casas and Caballero (1996) scientifically confirmed, by means of morphological characters of fruits and seeds, the ethnoclassification of varieties of Leucaena esculenta.

The aim of this study was to verify the consistency of the ethnoclassification of Brazil nut trees in Vale do Rio Acre by comparing morphological and molecular data. 


\section{MATERIAL AND METHODS}

\section{Study site}

The study was conducted in four areas in southwest Acre State, two in conservation units and two on private properties. The four areas were identified as follows: 1) Colônia São João - located in Seringal Petrolina, Senador Guiomard municipality, with an area of 220 ha; 2) Fazenda Nova Jerusalém - located in the municipality of Plácido de Castro, with an area of 300 ha; 3) Colocação Rio de Janeiro - located in the Seringal Filipinas, Reserva Extrativista Chico Mendes, Epitaciolândia municipality, with an area of 420 ha; and 4) Embrapa Acre Forest Reserve - Rio Branco municipality, with an area of 720 ha.

\section{Morphological analysis}

In each of these areas, at least 50 mature trees were sampled (Table 1). All Brazil nut trees sampled were mapped and classified according to type (red or white Brazil nut tree) by an experienced extractor and by a botanical expert from EMBRAPA Acre. This classification was independently of each other.

To define the most significant morphological characters in the local classification of Brazil nut trees, 20 extractors from the municipality of Senador Guiomard were interviewed. This survey was used to define qualitative and quantitative characters of mature trees, fruits, and seeds, which were used by the botanical expert to characterize the mapped trees.

The characters that helped to differentiate the types were: diameter at breast height (DBH), shape of the trunk, trunk base, and crown type. All trees were mapped and characterized using these variables with the following categories: straight trunk (trunk with the same thickness from base to insertion of the crown) or conical (trunk narrower at insertion of the crown and wider at base); base of the trunk straight (when the base of the trunk was flat at ground level) or with protrusions (bumps on the base at ground level); crown umbrella-shaped (branches open, wide, ramified, arranged almost perpendicular to the axis of the trunk), or crown tall (branches growing upwards).

Due to the high annual variation in the production of Brazil nut fruits (Kainer et al., 2007), we evaluated this variable only in Colocação Rio de Janeiro (Reserva Extrativista Chico Mendes), where we had cumulative nut production data for a sample of 133 trees for a 5-year period.

In the season 2005-2006, 15 red Brazil nut trees and 16 white Brazil nut trees were randomly selected to obtain morphometric data of fruits and seeds. For this selection, we discarded trees with poor or very poor crowns, because the shape of the crown affects fruit production (Wadt et al., 2005; Kainer et al., 2007).

Ten ripe fruits were randomly collected from the ground around each of the 31 selected Brazil nut trees, and used to obtain the following data: a) wet mass; b) length and width; c) pericarp thickness; d) shape of the operculum (ovoid or conical); e) number of seeds per fruit.

For the morphometric analysis of the seeds, 10 seeds of each fruit were randomly sampled and the following measurements were taken: length, width, and wet mass of all 10 seeds together. The dry mass of the fruits and seeds was obtained using samples of pericarp and 10 seeds of each fruit. Each sample was weighed to obtain wet mass and dried in an oven at $70^{\circ} \mathrm{C}$ for $24 \mathrm{~h}$. After drying, the samples were re-weighed and the moisture content calculated based 
on the mass of water lost. For statistical analyses, we estimated the average dry mass per seed by dividing the dry mass of the sample by 10 .

All statistical analyses were performed using SPSS for Windows 10.0.1 (standard version of 1999), where $\alpha=0.05$ indicated a significant difference. The frequencies of Brazil nut tree types between and within sites were evaluated using chi-square tests.

For the morphological characteristics of the trunk and canopy, we calculated the frequencies of occurrence of the category for each type using the Crosstabs procedure to test the association of the characteristics with the types. This association was tested in two ways: by using the lambda statistic for nominal directional measures (the independent variable values were used to predict the dependent variable, in this case, the type), and by the strength of association between the presence of a factor and the occurrence of an event (risk estimate). In this case, we tested whether the variables were associated with the type. These analyses were performed considering all trees, regardless of locations, and also for each of the study sites, to determine whether the results were consistent.

The quantitative variables DBH, production and morphometric data of fruits and seeds were first tested for normal distribution using the Shapiro-Wilk normality test. We used $t$-tests or Wilcoxon nonparametric statistics to see whether the types of Brazil nut tree had different mean values for these variables.

\section{Molecular analysis}

For the molecular study, we used DNA samples extracted from Brazil nut tree leaves collected in Colônia São João. The classification of Brazil nut trees in this area was confirmed by drilling the trunk and examining the wood color, eliminating any doubts regarding their classification, since this is the most striking characteristic. The collection of Brazil nut tree leaves is very difficult, due to the height of the trees $(40$ to $50 \mathrm{~m})$. We collected samples from 12 white and 12 red Brazil nut trees. All samples were dried in silica gel. Genomic DNA isolation was performed using a 2\% CTAB method modified from Doyle and Doyle (1990). Each sample was quantified on a $1 \%$ agarose gel against standard DNA ( $\lambda$ DNA). Each DNA sample was diluted to a working concentration of $1.0 \mathrm{ng} / \mu \mathrm{L}$.

A bulked segregant analysis (BSA) using random amplified polymorphic DNA (RAPD) markers and inter-simple sequence repeats (ISSR) was performed. Two DNA bulks were prepared using these samples: bulk R, containing samples from red Brazil nut trees, and bulk W, the white ones, both with a final concentration of $1.0 \mathrm{ng} / \mu \mathrm{L}$.

The bulks were analyzed using 95 RAPD primers from Operon Technologies and 29 ISSR primers designed for maize (Barcaccia et al., 2002). We selected RAPD and ISSR primers that generated a unique band for any of the bulks and also other RAPD primers that showed clear and polymorphic bands. PCR amplifications were then carried out for the 24 individual DNA samples using the selected primers. All PCR contained 1 to $5 \mathrm{ng}$ DNA, $30 \mathrm{ng}$ primer, $0.2 \mathrm{mM}$ each dNTP, $0.2 \mathrm{mg} / \mathrm{mL}$ BSA, $1.3 \mathrm{U}$ Taq DNA polymerase, and $1 \mathrm{X}$ PCR buffer (10 mM Tris-HCl, $\mathrm{pH} 8.3,50 \mathrm{mM} \mathrm{KCl}, 1.5 \mathrm{mM} \mathrm{MgCl}$ ).

The 40-cycle program used for PCR amplifications was adapted from Williams et al. (1990): 1 min denaturation at $92^{\circ} \mathrm{C}, 1 \mathrm{~min}$ annealing at $35^{\circ} \mathrm{C}, 2 \mathrm{~min}$ extension at $72^{\circ} \mathrm{C}$, and a 10 -min final extension at $72^{\circ} \mathrm{C}$. The amplified fragments were separated by $1.5 \%$ agarose gel electrophoresis $(4 \mathrm{~h}$ at $120 \mathrm{~V}$ ) using an Invitrogen Ladder 1-kb standard DNA molecular weight marker and ethidium bromide staining. 
The gel electrophoresis images from each of the individual DNA samples were used to generate a band presence (1) and absence (0) matrix. The Jaccard genetic similarity coefficient, more suitable for intraspecific analyses, and DICE, best suited for studies of divergent materials, were calculated for this matrix. UPGMA (unweighted pair group method with arithmetic mean) cluster analysis was applied to obtain a dendrogram for each similarity coefficient calculated to identify a possible grouping of individuals according to the morphological profile (type). For each dendrogram, we calculated the cophenetic correlation coefficient between the matrix of genetic similarities and the matrix of cophenetic values. The analyses were performed using the NTSYS 2.1 (Numerical Taxonomy and Multivariate Analysis System) program (Rohlf, 1989). For each analysis, the coefficient of variation of the estimates was calculated with dBoot 1.1 (Coelho, 2002) and 10,000 bootstrap resamplings from the Jaccard and DICE coefficients were used to see if the number of polymorphic markers was sufficient.

The separation and limits of the groups of individuals in the dendrograms were determined using Structure 2.3.1 (Pritchard et al., 2000), with the number of groups $(K)$ varying between 1 and 4, admitting mixture of genomes, 500,000 resamplings, and 50,000 burn-ins using Markov chain Monte Carlo (MCMC) method.

\section{RESULTS AND DISCUSSION}

\section{Morphological characteristics}

Of the 334 Brazil nut trees mapped in the four study areas, $216(65 \%)$ were classified as red Brazil nut trees and $118(34 \%)$ as white Brazil nut trees. Although the chi-square tests showed a higher frequency of red Brazil nut trees $(\mathrm{P}<0.0001)$ compared to the total, this pattern was not consistent when analyzing each area separately. In Colocação Rio de Janeiro and Fazenda Nova Jerusalém, more than $70 \%$ of Brazil nut trees were red. However, in Colônia São João and Embrapa Acre Forest Reserve, the frequencies of red and white Brazil nut trees were similar $(\mathrm{P}=0.274$ and $\mathrm{P}=0.777$, respectively).

Considering all the areas, the average DBH of red Brazil nut trees $(112.04 \pm 33.73 \mathrm{~cm})$ was significantly higher compared to white trees $(83.91 \pm 31.53 \mathrm{~cm})$. The two tree types did not differ in mean DBH only in Colocação Rio de Janeiro (Table 1). Brazil nut trees sampled in Colocação Rio de Janeiro are part of another study that monitors annual production, and the lack of difference in mean DBH between the types of Brazil nut trees in this area can be explained by the selection criteria of the trees, since there has been a control in their diameter to monitor production (Kainer et al., 2007).

\begin{tabular}{|c|c|c|c|c|}
\hline \multirow[t]{2}{*}{$\overline{\text { Site }}$} & \multicolumn{2}{|c|}{ White Brazil nut tree } & \multicolumn{2}{|c|}{ Red Brazil nut tree } \\
\hline & $\mathrm{N}$ & Mean DBH $(\mathrm{cm})( \pm \mathrm{SD})$ & $\mathrm{N}$ & Mean DBH $(\mathrm{cm})( \pm \mathrm{SD})$ \\
\hline $\begin{array}{l}\text { São João } \\
\end{array}$ & 45 & $80.01( \pm 28.47)^{* * *}$ & 56 & $116.93( \pm 31.34)^{* *}$ \\
\hline Rio de Janeiro & 38 & $102.92( \pm 36.19)^{\mathrm{NS}}$ & 95 & $101.13( \pm 36.56)^{\mathrm{NS}}$ \\
\hline Embrapa & 24 & $67.20( \pm 18.69)^{* *}$ & 26 & $133.05( \pm 29.14)^{* *}$ \\
\hline Nova Jerusalém & 11 & $70.63( \pm 10.54)^{* * *}$ & 39 & $117.59( \pm 22.02)^{* *}$ \\
\hline
\end{tabular}

${ }^{\mathrm{NS} M e a n s}$ on the same line did not differ significantly between the types of Brazil nut tree with the $t$-test; **Means on the same line differed significantly between the types of Brazil nut tree with the $t$-test using a $1 \%$ significance level. 
Considering all the Brazil nut trees, regardless of location, the variables crown and trunk shape were significant and consistent for the classification of the types $(\mathrm{P}<0.001$ for both), both by the lambda analysis and by the risk estimate, while the variable trunk base was not able to predict the type $(\mathrm{P}=0.69)$. A similar result was obtained when the local factor was considered in the analysis.

Although the shapes of the crown and trunk of the Brazil nut trees were consistent with the classification of the types made by the extractor and botanical expert, the frequency of occurrence of each variable for the aspects analyzed (Table 2) showed that all combinations of the classification were present. Furthermore, $8 \%$ of the trees for which the trunk was drilled to confirm the classification, showed other morphological characteristics that contrasted with the type according to the wood color, that is, red wood with morphological characteristics of white Brazil nut trees or vice versa. These results raise the hypothesis of the existence of intermediate morphotypes.

Table 2. Percentage of occurrence of morphological variables of the tree for the red and white types of Brazil
nut tree (Bertholletia excelsa Bonpl.).
\begin{tabular}{lcccccccc}
\hline Type & \multicolumn{3}{c}{ Crown } & & \multicolumn{2}{c}{ Trunk } & & \multicolumn{3}{c}{ Trunk base } \\
\cline { 2 - 3 } & Tall & Umbrella-Shaped & & Straight & Conical & & Straight & With protuberances \\
\hline White & 63.6 & 36.4 & & 11.9 & 88.1 & & 44.9 & 55.1 \\
Red & 9.7 & 90.3 & & 73.1 & 26.9 & & 22.7 & 77.3 \\
\hline
\end{tabular}

$\mathrm{PC}=$ up; $\mathrm{GC}=$ umbrella.

The average yield of red Brazil nut tree fruits $(75.5 \pm 89.7$ fruits/year) was significantly higher than that of white Brazil nut tree fruits $(31.1 \pm 29.9$ fruits/year, $\mathrm{P}=0.004)$, as the production of red Brazil nuts was almost 2.5 times that of white Brazil nuts.

The variation in the production of red Brazil nuts was much greater than in the production of white Brazil nuts. The annual variation in fruit production is common among Brazil nut trees (Prance and Mori, 1978; Zuidema and Boot, 2002; Kainer et al., 2007), although there is a positive relationship between consecutive years, that is, trees that produce few fruits in one year continue producing few fruits the following year, and the same happens to those that produce greater quantities of fruit (Baider, 2000; Kainer et al., 2007). Environmental factors, as well as genetic or physiological mechanisms of the plant, may explain these variations (Zuidema, 2003).

Brazil nut trees with greater DBH produce more fruits than those with smaller diameters (Baider, 2000; Zuidema and Boot, 2002; Wadt et al., 2005; Kainer et al., 2007), which may explain the increased production of red Brazil nut trees, as these had larger mean diameters than the white trees.

Of the 8 morphometric variables of fruits and seeds assessed for the 15 red and 16 white Brazil nut trees in Colocação Rio de Janeiro, only dry mass of 10 seeds and seed length showed no statistically significant difference between the types by analysis of variance. Generally, the fruits of red Brazil nut trees were larger, heavier, and had fewer seeds than the fruits from the white trees (Table 3).

In addition to the morphometric variables, we evaluated the shape of the operculum of the fruits of Brazil nut trees. Although red Brazil nut trees showed a tendency towards a conical operculum $(62.5 \%)$, there was no statistical association between type and operculum shape $(\mathrm{P}=0.479)$. 
Table 3. Morphometric variables of fruits and seeds sampled from 31 Brazil nut trees (Bertholletia excelsa Bonpl.) in Colocação Rio de Janeiro, Reserva Extrativista Chico Mendes, Acre.

\begin{tabular}{|c|c|c|c|c|c|c|}
\hline \multirow[t]{2}{*}{ Variable } & \multicolumn{2}{|c|}{ White Brazil nut tree } & \multicolumn{2}{|c|}{ Red Brazil nut tree } & \multicolumn{2}{|c|}{ All } \\
\hline & $\mathrm{N}$ & Means \pm SD & $\mathrm{N}$ & Means \pm SD & $\mathrm{N}$ & Means \pm SD \\
\hline Seed length $(\mathrm{cm})^{\psi}$ & 143 & $4.09 \pm 0.38^{\mathrm{NS}}$ & 160 & $4.11 \pm 0.27^{\mathrm{NS}}$ & 303 & $4.10 \pm 0.33$ \\
\hline Seed width $(\mathrm{cm})^{\psi}$ & 143 & $2.47 \pm 0.21^{* *}$ & 160 & $2.52 \pm 0.16^{* *}$ & 303 & $2.49 \pm 0.18$ \\
\hline Fruit length $(\mathrm{cm})^{\psi}$ & 143 & $10.34 \pm 0.69 * *$ & 160 & $10.84 \pm 0.72 * *$ & 303 & $10.60 \pm 0.75$ \\
\hline Fruit width $(\mathrm{cm})^{\psi}$ & 143 & $9.89 \pm 0.77 * *$ & 160 & $10.13 \pm 0.78^{* *}$ & 303 & $10.02 \pm 0.78$ \\
\hline Dry mass of fruit $(\mathrm{g})^{\S}$ & 143 & $373.07 \pm 115.0 * *$ & 160 & $430.27 \pm 113.15^{* *}$ & 303 & $403.27 \pm 117.38$ \\
\hline Dry mass of 10 seeds $(\mathrm{g})^{\S}$ & 143 & $57.74 \pm 17.7^{\mathrm{NS}}$ & 160 & $58.50 \pm 18.94^{\mathrm{NS}}$ & 303 & $58.14 \pm 18.34$ \\
\hline Pericarp thickness $(\mathrm{cm})^{\S}$ & 143 & $1.03 \pm 0.22 * *$ & 160 & $1.16 \pm 0.19^{* *}$ & 303 & $1.10 \pm 0.21$ \\
\hline Number of seeds & 143 & $17.83 \pm 3.07 *$ & 160 & $17.11 \pm 2.73^{*}$ & 303 & $17.45 \pm 2.91$ \\
\hline
\end{tabular}

${ }^{\Psi}$ Variables tested by the $t$-test; ${ }^{\S}$ variables tested by the non-parametric Wilcoxon test. ${ }^{\text {NS}}$ Means do not differ significantly between the types. *Means in the same row differ between types of Brazil nut trees at a significance level of 5\%; ** Means in the same row differ between types of Brazil nut trees at a significance level of $1 \%$.

According to Almeida (1963), the diameter of the fruit of the Brazil nut tree varies from 10 to $15 \mathrm{~cm}$ (10 cm for fruits in the Tocantins River and $15 \mathrm{~cm}$ for the Trombetas River) and the weight varies from 1-2 kg. The number of seeds varies from 10 to 25 per fruit. Almeida (1963) also mentions that there may be natural variation in seed size between different populations of Brazil nut trees, for example, the seeds from the Trombetas River are considered the largest, and those from Acre are recognized as the smallest in the whole Amazon.

Müller et al. (1980) and Moritz (1984) observed a positive correlation between fertilization rate, fruit size, weight, and permanence on the tree. Moritz (1984) reports that the development of new fruit depends on the number of seeds, since they are the main centers for the production of hormones that cause the nutrients to reach them, despite the competition with other plant parts.

Bruce Nelson (personal communication cited by Mori and Prance, 1990) suggests that for Bertholletia, the intrapopulation variation, both in seed size and the number of seeds per fruit, can be as large as interpopulation variations. However, in one individual, seed size, number of seeds per fruit and number of fruits per year would be relatively constant. The results of this study show that these variables are not very constant in a given individual because changes were observed in both seed size and the number of seeds from different fruits of the same tree. There were records of 11 and 21 seeds in fruit of the same tree. The fact that red Brazil nut trees had larger diameters, wider crowns with thicker branches, and higher fruit production raises the possibility that the types of Brazil nut are simply trees of different ages, the white ones being younger than the red ones.

\section{Molecular characteristics}

Of the 124 primers tested with the bulks R and W, 17 (11 RAPD and 6 ISSR) had the potential to differentiate between types of Brazil nut trees; that is, one band was exclusive to one of the bulks. These 17 primers, when used to generate profiles of the 24 individuals, did not show that the band was exclusive for all individuals of the same type.

The matrix of presence and absence of bands used for the analysis was generated using: a) the results of 11 RAPD primers and 6 ISSR primers and b) the results of fragment amplification with 33 RAPD primers that did not have an exclusive band for one type of Brazil nut tree 
during the screening, but were polymorphic. Gels with well-defined bands and with a small amount of amplification failures of the samples were selected for the matrix construction.

In this analysis of the individual profiles, a total of 161 markers with polymorphisms were obtained. These were used to construct the dendrograms. The dendrograms generated with the Jaccard and DICE coefficients were similar, differing only in branch length, and no groupings differentiated between red Brazil nut trees and white ones (Figure 1). In general, the polymorphism identified between the 24 trees analyzed was low, corroborating other genetic studies conducted in this species. In Pará, a study using isozyme markers found little variability, little genetic differentiation between populations (Buckley et al., 1988), and a high outcrossing rate (O'Malley et al., 1988). In another study, in the State of Acre, low variability in isozyme analysis was also found (Pardo, 2001). The values obtained for the correlation coefficient between the matrix of genetic similarities and the matrix of calculated cophenetic values were similar for analyses using the Jaccard coefficient $(r=0.726)$ and the DICE coefficient $(\mathrm{r}=0.722)$.

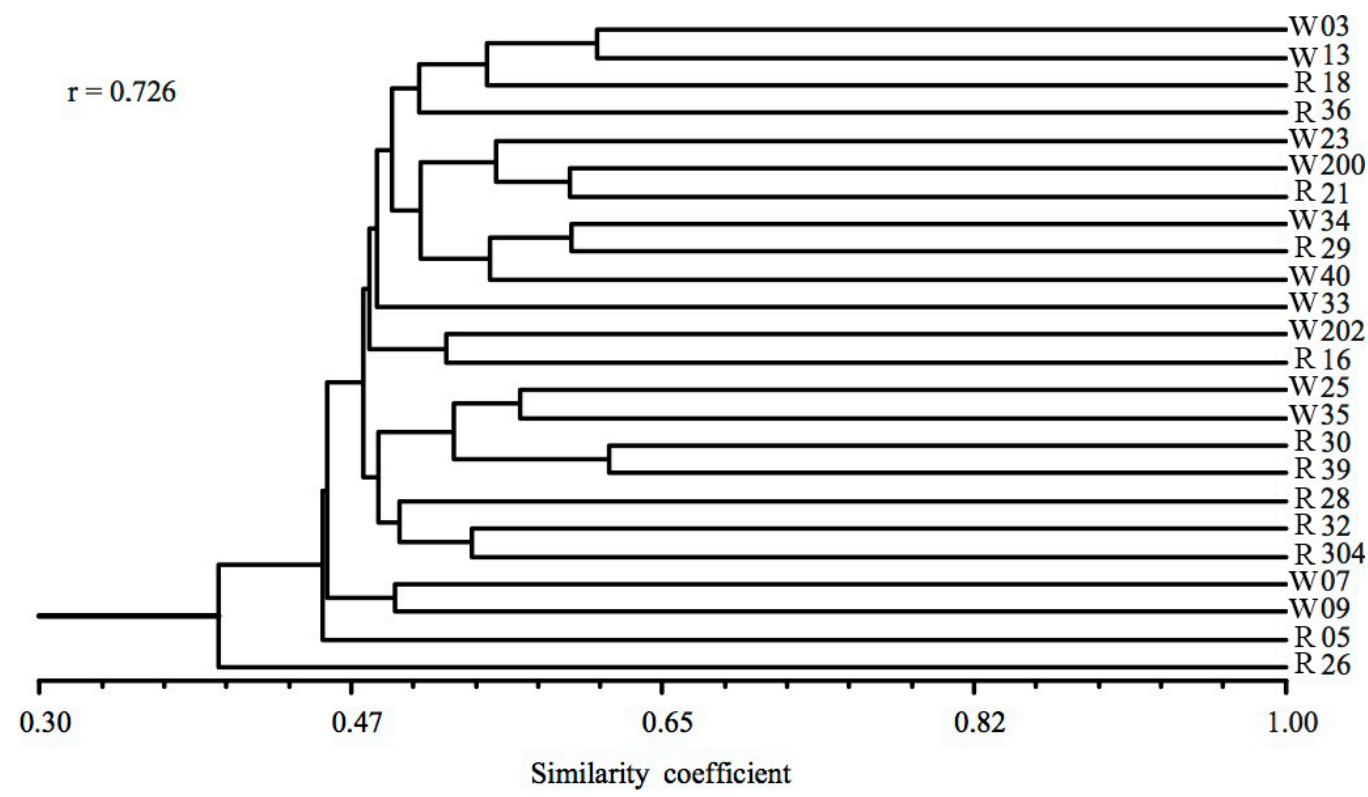

Figure 1. Dendrogram generated by the UPGMA cluster method representing the similarity based on Jaccard coefficient between individuals of white (W) and red (R) Brazil nut trees (Bonpl.) sampled at Colônia São João, Seringal Petrolina, Senador Guiomard municipality, State of Acre.

The coefficient of variation obtained from the Jaccard and DICE coefficients was 9.67 and $6.03 \%$, respectively, indicating that the number of markers used was sufficient.

An estimate of the number of groups and the limits between groups indicated that the individuals belong to a single group. None of the $K$ values showed a better fit with the data, and the probability of any individual belonging to any cluster was the same.

Studies based on RAPD and ISSR bands can be very useful in obtaining low-cost and fast results (Hadrys et al., 1992), despite the need for great care to ensure reliability. Besides, 
results from analyses with SSR markers and plants from other locations showed similar results, with no differentiation of red and white types (Sujii PS, Martins K, Wadt LHO, Azevedo VCR, et al., unpublished results).

These results are a strong indication that the ethnoclassification of Brazil nut trees as red or white may not have a genetic basis. It is possible that the characteristics used to describe them as white or red, actually vary according to plant growth and may not be considered as a descriptor but as a characteristic that may vary with age.

We detected the existence of Brazil nut trees with every possible combination of morphological characteristics and Brazil nut trees in which the classification did not correspond to any characteristic, despite the significant statistical results for the majority of the morphological characters. The results obtained with the molecular markers indicate that the Brazil nut trees classified as red and white do not differ genetically.

\section{ACKNOWLEDGMENTS}

We thank Empresa Brasileira de Pesquisa Agropecuária (EMBRAPA; units Acre and Recursos Genéticos e Biotecnologia), Fundação de Tecnologia do Estado do Acre (FUNTAC; grant DCR to K. Martins), Instituto Internacional de Educação do Brasil (IIEB), and Gordon and Betty Moore Foundation (grant to E.T.M.B. Fernandes) for financial and technical support.

\section{REFERENCES}

Almeida CP (1963). Castanha do Pará: Sua Exportação e Importância na Economia Amazônica. Serviço de Informação Agrícola, Rio de Janeiro, 1-86.

Baider C (2000). Demografia e ecologia de dispersão de frutos de Bertholletia excelsa Humb. \& Bonpl. (Lecythidaceae) em castanhais silvestres da Amazônia Oriental. Doctoral thesis, USP, São Paulo.

Barcaccia G, Molinari L, Porfiri O and Veronesi F (2002). Molecular characterization of emmer (Triticum dicoccon Schrank) Italian landraces. Genet. Resour. Crop Evol. 49: 417-428.

Buckley DP, O’Malley DM, Apsit V, Prance GT, et al. (1988). Genetics of Brazil nut (Bertholletia excelsa Humb. \& Bonpl.: Lecythidaceae). Genetic variation in natural populations. Theor. Appl. Genet. 76: 923-928.

Camargo FF (2010). Etnoconhecimento e variabilidade morfológica de castanha-do-brasil (Bertholleita excelsa Bonp.: Lecythidaceae) em área da Amazônia mato-grossense. Master's thesis. UFMT, Cuiabá.

Casas A and Caballero J (1996). Traditional management and morphological variation in Leucaena esculenta (Fabaceae: Mimosoideae) in the Mixtec region of Guerrero, Mexico. Econ. Bot. 50: 167-181.

Clement CR, Souza NR, Rodrigues DP, Astolfi-Filho S, et al. (2002). Uso de AFLPS para discriminar raças primitivas de pupunha (Bactris gasipaes) na Amazônia brasileira. Sci. Agric. 59: 749-753.

Coelho AS (2002). BoodP: Avaliação dos erros associados a estimativas de distância/similaridades através do procedimento de bootstrap com número de variáveis de marcadores (software). Laboratório de Genética Vegetal. Instituto de Ciências Biológicas. UFG. Distributed by the author, Goiânia.

Doyle JJ and Doyle JL (1990). Isolation of plant DNA from fresh tissue. Focus 12: 13-15.

Fernandes ETMB (2007). Diversidade morfológica e produção de Bertholletia excelsa H.B.K. (Lecythidaceae) no sudeste do Estado do Acre - Brasil. Master's thesis. UFAC, Rio Branco. (Autor não citado no texto final)

Hadrys H, Balick M and Schierwater B (1992). Applications of random amplified polymorphic DNA (RAPD) in molecular ecology. Mol. Ecol. 1: 55-63.

Kainer KA, Wadt LHO and Staudhammer CL (2007). Explaining variation in Brazil nut fruit production. For. Ecol. Manage. 250: 244-255.

MMA (Ministério do Meio Ambiente) (2008). Instrução Normativa MMA n 06/2008. Lista das espécies da flora brasileira ameaçada de extinção.

Mori SA and Prance GT (1990). Taxonomy, Ecology and Economic Botany of the Brazil Nut (Bertholletia excelsa Humb. \& Bonpl.: Lecythidaceae). Adv. Econ. Bot. 8: 130-150.

Moritz A (1984). Estudos Biológicos da Floração e Frutificação da Castanha-do-Brasil. EMBRAPA, CPATU, Belém.

Genetics and Molecular Research 12 (3): 4018-4027 (2013)

CFUNPEC-RP www.funpecrp.com.br 
Müller CH, Rodrigues IA, Müller AA and Müller NRM (1980). Castanha-do-Brasil: Resultados de Pesquisa. EMBRAPACPATU, Belém.

O’Malley DM, Buckley DP, Prance GT and Bawa KS (1988). Genetics of Brazil nut Bertholletia excelsa Humb. and Bonpl.: Lecythidaceae). 2. Mating system. Theor. Appl. Genet. 76: 929-932.

Pardo M (2001). Estrutura Genética de Castanha do Brasil (Bertholletia excelsa H.B.K.) em Floresta e em Pastagens no Leste do Estado do Acre. Master's thesis. Escola Superior de Agricultura Luiz de Queiroz, USP, Piracicaba.

Prance GT and Mori SA (1978). Observations on the fruits and seeds of neotropical Lecythidaceae. Brittonia 30: 21-33.

Pritchard JK, Stephens M and Donnelly P (2000). Inference of population structure using multilocus genotype data. Genetics 155: 945-959.

Rohlf FJ (1989). NTSYS-Pc: Numerical Taxonomy and Multivariate Analysis System. Exeter publishers, New York.

Wadt LHO, Kainer KA and Gomes-Silva DAP (2005). Population structure and nut yield of Bertholletia excelsa stand in Southwestern Amazonia. For. Ecol. Manage. 211: 371-384.

Williams JG, Kubelik AR, Livak KJ, Rafalski JA, et al. (1990). DNA polymorphisms amplified by arbitrary primers are useful as genetic markers. Nucleic Acids Res. 18: 6531-6535.

Zuidema PA and Boot RGA (2002). Demography of the Brazil nut tree (Bertholletia excelsa) in the Bolivian Amazon: impact of seed extraction on recruitment and population dynamics. J. Trop. Ecol. 18: 1-31.

Zuidema PA (2003). Ecology and Management of the Brazil nut Tree (Bertholletia excelsa). PROMAB Scientific Series 6, PROMAB, Riberalta. 